is, the pigment without $\mathrm{H}_{2} \mathrm{O}$ (water) and $\mathrm{C}_{3} \mathrm{H}_{4} \mathrm{O}_{4}$ (malonic acid?), corresponding to the cleavage product from yeast of Warburg and Christian.

(5) The oxidation product of the photochemical cleavage product, soluble in ether (free from nitrogen?).

Warburg and Christian have described the evolution of urea from their photochemical cleavage product by treatment with alkali, by which means the remaining substance, $\mathrm{C}_{9} \mathrm{H}_{10} \mathrm{O}_{2} \mathrm{~N}_{2}$, loses its whole power of fluorescence and all but a small remnant of its colour. It must be accepted that in this treatment an intramolecular transformation of the remaining substance also takes place; for our probably nitrogen-free oxidation product, obtained from the product of photochemical cleavage, still possesses fluorescence and colour to such an extent that the nitrogen content is very unlikely to have any connexion with these properties.

The three starting-points of the researches leading to the discovery of the new group of animal pigments-namely, the functions of the liver and the kidney, the respiratory ferment, and the action of vitamin $B_{2}-$ together indicate the great physiological importance of this new class of pigments. While the function of the Lyochromes as respiratory ferment is completely explained, their character as vitamin $B_{2}$ still requires further in. vestigation, since in the researches so far made their effect as vitamin $B_{2}$ was evident only with the addition of chemically unknown substances. The physiological significance of the occurrence of Lyochrome in the kidney and the liver is still quite unknown. On the respiration of normal tissue cells Lyochromes have no effect, as we ourselves, and also Wagner-Jauregg and Ruska ${ }^{8}$, have observed. On the other hand, Stern and Greville ${ }^{9}$ found that mammalian red blood corpuscles, which have practically no intrinsic respiratory activity, show a significant increase of oxidation in the presence of Lyochrome. It is very probable, how ever, that the substances used in these experiments as Lyochromes were not of that character; for, according to the investigations of one of us on the Lyochromes of the urine, the Urochrome used by Stern and Greville for their respiration experiments has no Lyochrome properties.

To summarise: The Lyochromes are characterised by the following qualities: (1) solubility in water ; (2) red to orange colour of the crystals, and orange to yellow colour of their watery solutions ; (3) yellow-green fluorescence; (4) extinction of this fluorescence by acid and alkaline reactions; (5) reversible reduction to leuco-substances; stability against oxidising agents.

The chemical investigation of the group, in spite of the small concentration of the Lyochromes in organic materials, has already advanced so far that in the near future we may expect that their chemical structure will be revealed, and that a knowledge of new relations between chemical constitution and physiological action will be afforded thereby.

'The method of 'intravital microscopy' has been described by Ph. Ellinger and A. Hirt in the Zeitschrift für Anatomie und Ent wicklungsgeschichte, vol. 90, p. 791, 1929, and in "Abderhalden Handbuch der biologischen Arbeitsmethoden", vol. 5, II , p. 1753 1930. It permits living animal organs to be examined with the strongest microscopical magnifications by injecting the animal with fluorescent dyestuffs. With ultra-violet illumination these dyes provide, by fluorescence in the cells themselves, the light required for visible illumination of the microscopical picture.

${ }_{2}$ Bleyer and Callmann, Biochem. Z., 155, $54 ; 1925$.

${ }^{3} \mathrm{O}$. Gerngross and M. Schulz, Milchwirtschaftliche Forschung, 6, $567 ; 1928$.

Details of this procedure as well as of further chemical operations are described in our publications: Ph. Ellinger and W. Koschara, Berichte der Deutschen Chemischen Gesellschaft, 66, 315, 808, 1411 ; 1933

Wage had made an agreement with $\mathbf{R}$. Kuhn, P. Györgyi and Th. Wagner-Jauregg, who worked over the same field and who called their substances 'Flavins', to call the whole group 'Lyochromes' and their single specimens 'Flavins', with the addition of the names of the materials of origin, so that the Flavin from milk is called 'Lactolavin'.

Warburg and Christian, Biochem. Z., 257, 492 ; 1933.

${ }^{7}$ R. Kuhn, P. Györgyi and Th-Wagner-Jauregg, Ber. Deutschen Chem. G'esell., 68, 317, 576, 1034, 1577; 1933.

${ }^{8}$ Th. Wagner-Jauregg and H. Ruska, Ber. Deutschen Chem. Gesell., 66, 1298; 1933.

• K. G. Stern and G. D. Greville, Naturwissenschaften, 22, 720 ; 1933.

\title{
Obituary
}

\section{Prof. F. LL. Griffith}

$\mathrm{F}^{\mathrm{R}}$ RANCIS LLEWELLYN GRIFFITH, whose death at the age of seventy-one years occurred on March 14, was, like a number of other distinguished Englishmen, the son of a clergyman, the Rev. John Griffith, who was for many years rector of Sandridge, Herts, and a mathematician of some repute. After being educated at Brighton College, Sedbergh and Highgate, he came up to Oxford as a scholar of Queen's College, where, under the influence of Prof. A. H. Sayce, he began those studies which were destined to win him later a world-wide fame. He took his B.A. degree in 1884, and during the winter seasons of that and the three following years he was engaged in excavation and other research work in Egypt under the leadership of Petrie and Naville. For some months of the season $1886-87$ he was busy copying the inscriptions in the tombs of the First Intermediate Period and Middle Kingdom at Asyût and Dêr Rîfeh. His publication of these texts ("The Inscriptions of Asyût and Dêr Rîfeh", 1889) not only shows that even at this early date he had acquired a sound knowledge of Middle Egyptian, but already displays that scholarliness and meticulous accuracy which are so characteristic of all his subsequent work.

From 1888 until 1896, Griffith was an assistant in the Department of British and Mediæval Antiquities in the British Museum. In 1892 he was made assistant professor of Egyptology at University College, London, a post which he retained until he was appointed reader of Egyptology at Oxford in 1901. During those years his output was remarkable both for quantity and quality, its crowning achievement being the 
publication in two volumes of Petrie's great find of papyri at Kahun and Gurob. Most of these are documents written in the cursive business hieratic of the Middle Kingdom, a script of which there had hitherto been found few, if any, examples. In his mastery of this difficult script and in his interpretation of the contents of the documents, Griffith showed that he possessed that rare gift-real genius. Many years have passed since those two volumes appeared, and there has been a great advance in our knowledge of Middle Egyptian grammar and syntax, but even so, Griffith's translations and transcriptions need comparatively few corrections.

For the next ten years or so Griffith devoted himself primarily to the study of Demotic, and by the end of that period was the foremost Demotic scholar in the world. His "Stories of the High Priests of Memphis" (1900), the "Demotic Magical Papyrus of London and Leyden", which he produced in collaboration with Sir Herbert Thompson (1907-9), and above all his "Catalogue of the Demotic Papyri in the Rylands Library" (1909) placed Demotic studies on a new footing, and gave them an interest which, in the minds of some of us at any rate, they had hitherto seemed to lack.

About the year 1907, Griffith found opportunity for winning laurels in a new field. Excavations in the Sudan and Lower Nubia were producing inscriptions in the Meroitic script hitherto undeciphered, and the finders handed them over to him to investigate. After a few years of intensive study, he could decipher the script and had advanced far towards a complete understanding of the language.

In due course Griffith turned back to Demotic and was actually engaged at the time of his death in the publication of the Demotic inscriptions occurring in the temple of Philae and in the temples of Lower Nubia, a great and most important undertaking.

In the winter season 1910-11, Griffith and his wife conducted excavations on behalf of the University of Oxford in Lower Nubia, and they continued these activities until the winter season 1913-14. In 1922 and 1923 they excavated for the Egypt Exploration Society at El-Amarna. Twice since then they have excavated in the Sudan, the site of their last campaign (1930-31) being Kawa, where they unearthed three temples, one of which had been founded by Tirhaqa. At Kawa, beside several large stelæ bearing inscriptions of great historical interest, they found a number of reliefs and statues and a quantity of other antiquities, some being of considerable artistic merit.

In 1924, in consideration of his services to Egyptology and to the University of Oxford, Griffith was given the status of professor, and, though he resigned the chair in 1932, he acted as deputy professor until the late Prof. Peet was transferred from the University of Liverpool to succeed him in October 1933. Griffith was a D.Litt. of Oxford, an honorary fellow of Queen's College, a fellow of the British Academy and also of the Society of Antiquaries, an honorary LL.D. of the University of Aberdeen and an honorary D.Phil. of the University of Leipzig. He was a correspond. ing member of the Royal Academy of Sciences at Berlin, and a foreign associate or corresponding member of many other famous learned societies in Europe.

$\mathrm{He}$ was twice married, and his second wife, who has rendered him notable assistance in his excavations in Egypt, Lower Nubia and the Sudan, and in the production of many of his publications, survives him.

Griffith was a man of wide interests. Beside a profound knowledge of Egyptology in all its branches, he was well acquainted with the archæology of his own country and of foreign countries other than Egypt. He was very fond of music and was a good naturalist and botanist. $\mathrm{He}$ was a delightful companion for a country walk, pointing out and discussing any interesting flower or plant that he observed growing in hedgerow or field; and he knew every bird by its notes. It should here be stated that his great knowledge of the birds, fish and other animals of Egypt is made manifest in many of his books and articles. A charming trait in his character was his love of children, who found in him an ideal companion. He would take them round his garden and talk to them about the birds and plants, and the creatures living in stream or pond. Small children, frightened of strangers in general, took to him immediately and, when next he appeared on the scene, welcomed him with open arms.

His was a full life and he accomplished much. He died, as all would wish to die, in full possession of all his faculties and with his mind occupied to the last in the work he loved.

Alyward M. Blackman.

\section{Dr. H. S. WAShington}

Wiтh the death of Dr. Henry Stephens Washington on January 7 at the age of sixty-six years, petrology has suffered the loss of one who, for the past forty years, has worked with distinction and has contributed greatly to the advancement of the science.

Henry Stephens Washington was born at Newark, New Jersey, on January 15, 1867, and, after due preparation, he proceeded to Yale where he obtained, in 1886, the degree of B.A. with special honours in natural sciences. After two years of post-graduate work he graduated M.A. in 1888. The next four years were spent in travelling in the West Indies, Europe, Egypt, Algeria and Asia Minor, parts of the four winters and springs being spent in Greece where he became a member of the American School of Classical Studies. In the latter capacity he assisted in and conducted excavations at Plateae, Argos and Phlius. 